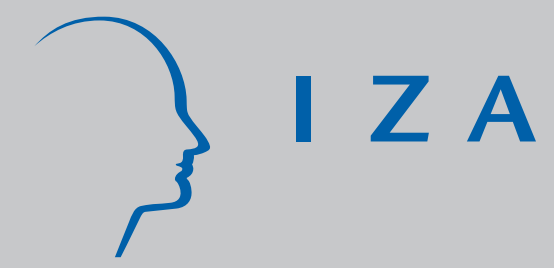

IZA DP No. 598

Credit Market Constraints and Labor Market Decisions

Daniela Del Boca

Annamaria Lusardi

October 2002 


\title{
Credit Market Constraints and Labor Market Decisions
}

\author{
Daniela Del Boca \\ University of Turin and IZA Bonn \\ Annamaria Lusardi \\ Dartmouth College \\ Discussion Paper No. 598
October 2002
}

IZA

P.O. Box 7240

D-53072 Bonn

Germany

Tel.: +49-228-3894-0

Fax: +49-228-3894-210

Email: iza@iza.org

This Discussion Paper is issued within the framework of IZA's research area Internationalization of Labor Markets. Any opinions expressed here are those of the author(s) and not those of the institute. Research disseminated by IZA may include views on policy, but the institute itself takes no institutional policy positions.

The Institute for the Study of Labor (IZA) in Bonn is a local and virtual international research center and a place of communication between science, politics and business. IZA is an independent, nonprofit limited liability company (Gesellschaft mit beschränkter Haftung) supported by the Deutsche Post AG. The center is associated with the University of Bonn and offers a stimulating research environment through its research networks, research support, and visitors and doctoral programs. IZA engages in (i) original and internationally competitive research in all fields of labor economics, (ii) development of policy concepts, and (iii) dissemination of research results and concepts to the interested public. The current research program deals with (1) mobility and flexibility of labor, (2) internationalization of labor markets, (3) welfare state and labor market, (4) labor markets in transition countries, (5) the future of labor, (6) evaluation of labor market policies and projects and (7) general labor economics.

IZA Discussion Papers often represent preliminary work and are circulated to encourage discussion. Citation of such a paper should account for its provisional character. A revised version may be available on the IZA website (www.iza.org) or directly from the author. 
IZA Discussion Paper No. 598

October 2002

\section{ABSTRACT}

\section{Credit Market Constraints and Labor Market Decisions*}

In this paper, we examine whether imperfections in credit markets spill over to other markets, particularly the labor market. We take the case of Italy, a country that experienced changes in the mortgage market brought about by the 1992 European unification and other institutional shifts. These events make Italy a good laboratory to study the effects of financial markets on the labor market. Using a simultaneous equation framework and household data from the Bank of Italy between 1989 and 1993, we estimate the relationship between female participation and mortgage use. We find a significant impact of mortgages on women's participation in the labor market.

JEL Classification: J2, D91

Keywords: mortgage market, female labor market participation

Corresponding author:

Daniela Del Boca

Department of Economics

University of Turin

Via Po 53

10124 Torino

Italy

Tel.: +39-11-6702 726

Fax: +39-11-6702 762

Email: daniela.delboca@unito.it

\footnotetext{
* We would like to thank Rob Alessie, Jim Davies, Gary Engelhardt, John Ermisch, Luigi Guiso, Tullio Jappelli and especially Christopher Flinn for suggestions and comments. Cesare Bastianini, Edi Grgeta, and Crandall Peeler provided excellent research assistance. We also thank seminar participants at the University of Copenhagen, CentER, University of Uppsala, Dartmouth College, New York University, University of Turin, and Cornell University. This research was supported by CNR (Italy) and Compagnia di San Paolo.
} 


\section{Introduction}

In this paper, we examine whether imperfections in credit markets spill over to the labor market. More specifically, we analyze whether restrictions in the mortgage market influence female labor market participation decisions. We consider the case of Italy, a country that experienced several changes in the mortgage market due to new banking legislation and financial liberalization brought about by the European unification in 1992. This provides us with a good laboratory to study the links between the credit markets and the labor market.

We utilize two cross-sections from the Bank of Italy's Survey of Household Income and Wealth (SHIW). One cross-section was collected in 1989 and the other in 1993. During this time, there were two important changes in the Italian mortgage market. First, foreign banks entered the domestic market and widened consumers' access to the mortgage market. This market expansion, together with new banking legislation, increased the competition among domestic banks. Second, families could finance a higher percentage of the total house price through a mortgage, even though mortgage duration remained relatively short. These changes made mortgages more readily available to a larger portion of the population, but also shifted the burden of homeownership from a large down-payment to greater mortgage payments.

Despite rising housing prices, the percentage of homeowners with a mortgage increased dramatically between 1989 and 1993, rising from 13 to 28 percent. At the same time, the percentage of working wives increased from 43.7 to 48.9 percent among homeowners, and from 45.4 to 50.4 percent among homebuyers. The objective of our study is to analyze the extent to which growth in the labor market participation of married women is linked to the increase in mortgage use. 
In our empirical work, we model the labor market participation of married women not only as a function of variables that can proxy for wages and household resources, but also as a function of the burden of a mortgage. We begin by estimating the direct impact of having a mortgage on the probability of married women working and find a positive and highly significant coefficient associated with this variable. Of course, there are a number of possible interpretations of this positive relationship. For example, it may be that households with working wives are more likely to qualify for a mortgage. Thus, the temporal dependence in participation decisions and having a mortgage may simply reflect the fact that the wife is more committed to the labor market and hence more likely to be found working at any point in time.

While we do not have access to panel data $\square_{\text {and cannot consider selection arguments }}$ that involve dynamics, we do allow for simultaneity between participation and mortgage decisions within a static dummy variable simultaneous equation framework (Heckman 1978). The model we estimate is nonrecursive; we allow for the participation decision to directly influence the likelihood of having a mortgage and having a mortgage to directly impact the likelihood of participation. While we believe that it is reasonable to assume bi-directional causality, our estimates seem to indicate that the model is "nearly" recursive. There seems to be only a small, marginally significant direct effect of the propensity to participate in the labor market on the likelihood of having a mortgage. The results of the simultaneous equation estimation lend credibility to the claim that the impact of having a mortage on participation is not solely due to selection issues.

In order to further investigate possible selection biases, we reestimate the model using data from households in which wives are relatively young. Given the more limited time for 
accumulating savings, these households are more likely to require a loan when buying a house. They are also more likely to benefit from the changes in the Italian mortgage market. While there is still evidence of simultaneity in this sample, there is no evidence of nonrecursiveness. This result seems to be coherent with our hypothesis that it is the changes in the mortgage market that affect participation in the labor market.

We have also reestimated the model after disaggregating the sample by region of residence. There were broader changes in the mortgage market in North and Central Italy where competition among banks is more intense and costs of default (to banks) are lower. There is still evidence of simultaneity but less of non-recursiveness.

The structure of this paper is as follows: Section 2 contains a discussion of previous research on this topic; Section 3 provides a description of the characteristics of the Italian mortgage market; Section 4 describes the data; Section 5 describes the econometric specification of the models and Section 6 reports the empirical estimates. Section 7 provides a short summary and concluding remarks.

\section{Previous Research}

Many studies have documented the effects of imperfections in financial markets on consumption and saving decisions (Browning and Lusardi 1996; Eberly 1994; Garcia et al. 1997; Zeldes 1989). One of the most important markets for consumer credit is the mortgage market, and a number of papers show how imperfections in this market affect household saving decisions (Engelhardt 1996; Caplin et al. 1997). Other studies show the various ways that households rely on family transfers to compensate for financial market imperfections. Haurin et al. (1995) found that about 14 percent of households receive gifts during the year of

\footnotetext{
${ }^{1}$ While there is a panel data component in the SHIW, it is too small for our study.
} 
home purchase, three times as many as the years prior to purchase. Guiso and Jappelli (2002), using 1991 Bank of Italy data, reported that family transfers help overcome liquidity constraints in housing purchases by shortening saving time by one to two years and allowing households to purchase considerably larger homes. Engelhardt and Meyer (1994) show that transfer recipients have overall lower savings, but purchase homes significantly earlier than non-recipients. Ermisch and Halpin (2000) also report important effects of family characteristics in determining homeownership in Great Britain.

The limitations of credit markets can affect other markets in general and, in particular, the labor market. Backus and Bernhardt (1990) demonstrate how borrowing constraints can influence the choice of occupation. Several other papers, including those by Evans and Jovanovic (1989), Evans and Leighton (1989), Blanchflower and Oswald (1998), and Fairlie (1999) show that financial constraints can limit entrance into self-employment or entrepreneurship. In addition, financial constraints can affect success and survival into entrepreneurship (Holtz-Eakin et al. 1994).

Other studies have analyized more specifically the relationship between financial contraints in the housing market and allocation of time within the households. Yoshikawa and Ohtake (1989) found a significant effect of the price of owning a house on female labor supply in Japan. Phillips and Vanderhoff (1991) report the effects of occupational choice on housing demand in the US.

Fortin (1995) considered the effects of mortgage constraints on labor market decisions. Using data from the 1986 Canadian Family Expenditures survey, she analyzed the impact of liquidity constraints on the mortgage market. Specifically, she estimated a labor supply model that incorporated a mortgage qualification constraint based on earnings. Her estimates 
indicate that a household's mortgage choices depend significantly on the existing level of the wife's labor earnings. Along these lines, Aldershof et al. (1996) examined the relationship between female labor supply and mortgage constraints for the Netherlands, finding that mortgage constraints play an important role in the female labor supply. Dau-Schmidt (1997) provided additional evidence on the impact of debt commitment on labor supply in the US. Del Boca and Lusardi (1999) used instrumental variables methods to explore the relationship between home financing decisions and female labor supply in cross-section data from Italy, reporting similar results as Aldershof et al. (1996).

While there is mounting evidence that a relationship exists between the female labor supply and mortgage debt commitments, it is hard to determine what this relationship indicates. Does this relationship result from liquidity constraints or does it highlight household preferences? Does it simply reflect the conditions that banks require when giving loans? For example, banks may prefer to lend primarily to two-earner families. We will try to address these concerns in the empirical work. We consider next a brief description of the institutional setting in Italy.

\section{The Institutional Setting}

We first consider some institutional factors that differentiate Italy from other advanced countries. Table 1 summarizes important mortgage market characteristics of selected countries. 


\section{Table 1: Characteristics of the Mortgage Market in Selected Countries}

$\begin{array}{lccc}\text { Countries } & \begin{array}{c}\text { Mortgage/ } \\ \text { house value }\end{array} & \begin{array}{c}\text { Duration of } \\ \text { mortgage loans }\end{array} & \text { Mortgages/GNP } \\ \text { Italy } & 50 & 10 & 4.7 \\ \text { Germany } & 60-80 & 25-30 & 45.0 \\ \text { Great Britain } & 75-100 & 25 & 46.4 \\ \text { France } & 80 & 10-20 & 23.6 \\ \text { U.S. } & 80-90 & 25-30 & 60.0\end{array}$

Source: European Mortgage Federation, 1989.

Compared to other countries, Italy has a low mortgage to house value ratio. Downpayment was high in Italy in 1989 and home-buyers were able to borrow only 50\% of the value of their house. Another peculiar feature of Italy was the short duration of mortgages. While in the US and in other European countries, home-buyers could borrow for a long time period ( 25 or 30 years), the duration of mortgages in Italy was only 10 years.

Another relevant characteristic of the mortgage market concerns transaction costs, which include the charges of real estate agents and taxes. In Great Britain transaction costs are approximately 4.5 percent of the value of the house, in Germany they are 12 percent, in France 16 percent, and in Italy 18 percent (Villosio, 1995). In addition, while in the U.S., Canada and Great Britain, loan applications are processed rapidly because of specialized credit reference agencies that are able to provide information on the credit record of potential borrowers, in Italy the process is much slower and more bureaucratic. A report from the Bank of Italy shows that part of the high transaction costs is associated with the complicated process of repossessing collateral (Generale and Gobbi 1995). It takes 5.5 years on average for an Italian bank to repossess collateral: 4.5 years in Northern and 6.6 years in Southern 
Italy. Given these characteristics, it is not surprising that the market for mortgages was rather small in Italy. The percent of mortgages over GDP was only $4.7 \%$ in 1989, in sharp contrast with the US, whose well-developed mortgage market was valued at 60\% of GDP.

Despite these mortgage market imperfections, the proportion of Italian homeowners is higher than in most other advanced countries. The overall home ownership rate has been continually rising. It increased from 46 percent in 1961 to 59 percent in 1981 and to 75 percent in 1995. Studies of the Italian housing market show that the high demand for homeownership stems from a lack of alternatives in the rental market. ${ }^{\text {Q }}$ Other studies have explained the high homeownership rate by the bequest motive, the low cost of higher education, the stability of the Italian family, and the very low geographic mobility.

Several important changes have affected the credit markets in Italy in the 1990s (Miles 1992). As mentioned above, 1992 marked the beginning of a period of financial liberalization throughout Europe. This change not only freed circulation of goods and services among European countries, but it also allowed for movements of capital and enhanced activities of banks across national borders. Several banks, especially British banks, entered the Italian credit market. For example, Abbey National, a British bank specializing in mortgages, was one of the first to open foreign branches in Italy. Ucb, Paribas, Banque Lazard, and Woolwich are among the other foreign banks that entered the Italian mortgage markets (Casini 1995). The resulting increase in banking competition pressured domestic banks to make their mortgages more accessible and to improve their terms. ${ }^{\text {B }}$ A comparison of conditions offered by foreign banks shows that Woolwich, Paribas, and Ucb allowed a maximum duration of 20

\footnotetext{
${ }^{2}$ The rental market has also been heavily regulated, creating a shortage of rental homes.

${ }^{3}$ Foreign banks were present in Italy before 1992, but their activity in the mortgage market was quite limited. For example, the number of loans provided by foreign banks was only 403 in 1989 versus 8,264 in 1992 (see Casini 1995).
} 
years, while Abbey National raised the maximum mortgage to 85 percent of house value. Along with improved financing terms, the length of time required for a mortgage application shortened and transaction costs decreased.

The level of downpayment required to buy a house is also important. If we consider homeownership by age, it appears that the proportion of young homeowners is much higher in countries where the downpayment ratio is low (Chiuri and Jappelli 2002). For example, the proportion of homeowners in the age cohort 26-35 is 49.29 and 63.8 in US and UK (countries with a low downpayment), while it is only 22.2 in Italy (Table 2). The decrease in the downpayment ratio has a potentially strong effect on the young, who are most likely to need a mortgage to finance a home purchase.

TABLE 2

Proportion of buyers by age

\begin{tabular}{lccc} 
& \multicolumn{3}{c}{ Age groups } \\
& $26-35$ & $36-45$ & $46-55$ \\
Countries & 22.20 & 54.40 & 66.00 \\
Italy & 63.80 & 75.06 & 74.54 \\
Great Britain & 34.78 & 61.88 & 68.62 \\
France & 49.29 & 71.61 & 78.94
\end{tabular}

Source: Luxembourg Income Study data reported in Chiuri and Jappelli (2002).

In addition to the effect of foreign competition, there was also a change in the Italian banking structure resulting from the Amato Act of 1990. This Act changed the mortgage 
market by allowing commercial banks to provide mortgage loans, formerly the responsibility of specialized credit institutions (Casini 1995). Other legislation (Law 175/1991) revised mortgage market regulation by reducing the legal constraint on the size of the downpayment.

These changes in competition and regulation had visible effects on the mortgage market. For example, the decrease in the downpayment made mortgages available to many households, particularly young ones, and the improved conditions induced more families to borrow from banks. In just a few years time, the mortgage market expanded and the ratio of mortgages to GPD increased. However, while the number of mortgages as well as their average amount increased, the duration of mortgages did not substantially change. While some banks, particularly foreign banks, allowed for a greater duration, the proportion of mortgages with durations longer than 10 years did not significantly increase during the period of observation. Short loan durations, combined with an increase in housing price and the amount borrowed from banks, contributed to a sharp rise in mortgage payments. The burden of the mortgage shifted from the accumulation of down-payment to the re-payment of mortgage debt. For example, by 1993, mortgage installments rose as high as 52 percent of family income (Villosio 1995).

Contrary to the Canadian case described in Fortin (1995), there is no specific earnings requirement required by law or by banking regulation in Italy. Nevertheless, banks use a set of criteria to gain a high "realized" interest rate on mortgages. For example, consistent with the evidence that it is more difficult to reposses collateral in the South, the mortgage market is much more developed in the Northern than Southern regions of Italy. Banks can also exploit their long-term relationship with customers to alleviate the problem of asymmetric information. 
Not only is the mortgage market rather imperfect, but the labor market also suffers from several restrictions in Italy. For example, while in most advanced countries the proportion of part-time employees is between 20-30 percent of the total work force, in Italy it is about 5-6 percent and has not increased in recent years. Other research focusing on the characteristics of labor supply in Italy shows that there are important constraints in the choice of hours of work (Del Boca and Flinn 1985; Aaberge et al. 1999). In Italy, the distribution of hours is highly concentrated around 35 hours for women and 40 for men.

The hypothesis we analyze and test in this paper is whether imperfections in the mortgage market have an effect on the labor market. More specifically, we analyze whether the opening of the credit market to many Italian families has induced women, in particular young ones, to participate to the labor market.

\section{Data and Empirical Findings}

The data we use are from the Bank of Italy's SHIW in 1989 and 1993. We select married couples in the age range of 21 to 59 for men and 21 to 55 for women to exclude individuals who are in school or close to retiring. Other selection criteria are described in Table A.1 in Appendix 1. ${ }^{4}$

We first note that about 20 percent of home-owners received their houses as gifts or bequests (Tables 3a). Thus, some families never face financing decisions when becoming home-owners. Consistent with evidence from other studies (Guiso and Jappelli 2002) and the existence of severe imperfections in the credit markets, we also find that Italian families

borrow not only from banks, but also from the network of the extended family. While only a few households use this informal channel of credit, the amount borrowed is not irrelevant. 
The conditional mean and median of family loans are 14.5-million and 9-million liras (approximately $\$ 9,000$ and $\$ 5,600$ ), respectively. While households report owing other debts, their total amount is much lower than family debts. The conditional mean and median of other debts are 7.2- and 5-million liras, respectively. However, the most relevant debt for many households is the mortgage debt. The survey provides information only on the residual

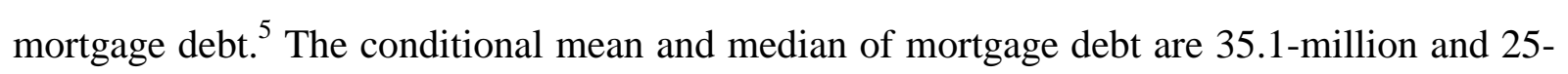
million liras respectively.

Table $3 \mathrm{a}$ and $3 \mathrm{~b}$ report some additional descriptive statistics of husbands' and wives' characteristics by different financing situations in 1989 and 1993. The critical point that emerges is that the labor market participation rate of women is correlated with the way families finance their homes. Among homeowners, women's participation rate is 43.7 and 48.9 percent (in 1989 and 1993 respectively). Among those who inherited a house or received it as a gift, the participation rate is much lower, at 41.1 and 42.7 percent. Participation is also much lower among renters. In households that financed their home purchase with a mortgage, the labor participation rate of wives is highest. Families that have a mortgage debt are also those where both husband and wife are younger, have higher education, are more likely to live in the North and to work more hours. Households with a mortgage are also more likely to have other debts.

Simple comparisons across years show that the degree to which households accessed the mortgage market changed rapidly, as mentioned before in Section 3. The mortgage rate among homeowners more than doubled, going from 13 percent in 1989 to 28 percent in 1993, and the proportion of new homeowners with a mortgage (those who bought their house

\footnotetext{
5 The question related to the mortgage debt includes also mortgage debt for house restoration.

${ }^{6}$ The proportion of homeowning went from 62.2 to 67.4 .
} 
in the previous two years) increased from 44.8 to 61.1 percent. Not only did the proportion of mortgages go up, but also the amount borrowed increased. If we considered those who bought a house in 1988 and 1989, their (residual) mortgage debt is 30.65-million liras. For those who bought a house in 1992 or 1993, the remaining mortgage debt is almost double that amount, reaching 58.29-million liras.

There are other factors that indicate how the mortgage market has opened to many more families. For example, the average age of home-buyers went from 35.7 in 1989 to 34.3 in 1993. We examine the pattern of homeownership across age groups and find that younger households are the ones benefitting the most from the changes in the mortgage market. The rate of homeownership among households younger than 30 years increased sharply, going from 18.6 percent in 1989 to 43.6 percent in 1993. Similarly, we find that families buying homes with a mortgage in 1993 are less likely to have family debts than buyers in 1989. This suggests that families are relying more on credit markets rather than borrowing from their parents or relatives.

As we have discussed earlier, while the mortgage market has increased in size and opened to a larger number of households (for example, younger households and those with lower assets), the duration of the mortgage did not change remarkably, contributing to high repayment rates. The changes in the timing and burden of the responsibility of homeownership may have important implication for women participation in the labor market (inducing women to enter the labor market or to remain employed to help repaying the mortgage).

In our sample of home-owners, the female labor market participation rate increased from 43.7 percent in 1989 to 48.9 percent in 1993. The objective of our empirical work is to 
assess how much of the increase in labor market participation can be attributed to the increased use of the mortgage market. Given that the choice of working hours for Italian workers is basically a binary one, zero or 35 (or 40) hours a week, we do not consider female labor supply but instead the participation rate.

\section{Econometric Specification}

One attractive way to visualize the (short-run) effect that changes in financial market regulations have on mortgage usage and labor market participation rates of wives is the latent variable simultaneous equation model, first formulated by Heckman (1978). We think of the propensity of the wife to participate in the labor market and the propensity of the (homeowner) family to hold a mortgage as latent variables. The values of the latent variables themselves are not directly observed; instead only an indicator variable is observed if the value of each exceeds a certain threshold, which is particular to the variable considered. In order to identify the direction of causality, we rely on variables proxying for the credit system and, in particular, the changes in the mortgage market across different periods of time. We think of the changes in mortgage regulations as effectively lowering the threshold that maps the propensity to have a mortgage into actually holding one. If our hypothesis is correct, changes in the mortgage market will shift the intercept term only in the mortgage equation without altering any other characteristics of the structural model.

Below we discuss the models we estimate, which are based on a latent variable specification of mortgage and participation decisions. It is well-known that the interpretation of linear regression-type models is problematic when some or all of the dependent variables are binary, as is the case here. Latent variable models provide a useful framework for 
interpreting the relationships between discrete random variables at the cost of introducing some restrictions not present in the linear estimation case (particularly in the context of simultaneous equation systems).

We estimate two special cases of the type of simultaneous equation model involving latent variables proposed by Heckman (1978). The general structure is:

1) $\begin{aligned} & y_{1 i}^{*}=x_{1 i} \beta_{1}+\delta_{1} y_{2 i}^{*}+\eta_{1} y_{2 i}+\varepsilon_{1 i} \\ & y_{2 i}^{*}=x_{2 i} \beta_{2}+\delta_{2} y_{1 i}^{*}+\eta_{2} y_{1 i}+\varepsilon_{2 i}\end{aligned}$

where $\left(\begin{array}{l}\varepsilon_{1 i} \\ \varepsilon_{2 i}\end{array}\right) \approx N\left(\left[\begin{array}{l}0 \\ 0\end{array}\right],\left[\begin{array}{cc}1 & \rho \\ \rho & 1\end{array}\right]\right), \quad \forall i$;

and $\quad y_{k i}=\left\{\begin{array}{lll}1 & \text { if } & y_{k i}^{*}>0 \\ 0 & \text { if } & y_{k i}^{*} \leq 0\end{array}\right.$.

$y_{1 i}$ takes the value 1 if the wife in household $\mathrm{i}$ is participating in the labor market at the time of the interview and assumes the value 0 otherwise; $y_{2 i}$ takes the value 1 if household $\mathrm{i}$ currently holds a mortgage; $x_{1 i}$ and $x_{2 i}$ are vectors of exogenous variables in the participation and mortgage equations, respectively. The error term vector is $\varepsilon_{i}=\left(\begin{array}{ll}\varepsilon_{1 i} & \varepsilon_{2 i}\end{array}\right)$. The data available to estimate (1) consist of a random sample of observations on $\left\{y_{1 i}, y_{2 i}, x_{1 i}, x_{2 i}\right\}_{1=i}^{N}$. Such information is not sufficient to identify all the structural parameters that appear in (1). A number of restrictions on the model, typically referred to as "coherency conditions", are

\footnotetext{
${ }^{7}$ See Heckman (1978).
} 
required first to ensure logical consistency and then to secure identification in the classical sense.

We consider two specific cases (Model 1 and 2) of the general model:

$\begin{array}{ll} & \delta_{1}=\delta_{2}=0 \\ \text { Model 1: } & \eta_{2}=0 \\ & \rho=0 \\ & \\ & \\ \text { 2) } \quad & \begin{array}{l}y_{1 i}^{*}=x_{1 i} \beta_{1}+\eta_{1} y_{2 i}+\varepsilon_{1 i} \\ y_{2 i}^{*}\end{array}=x_{2 i} \beta_{2}+\varepsilon_{2 i}\end{array}$

Because the error terms are assumed to be uncorrelated $(\rho=0)$, there is no simultaneity in this specification. Having a mortgage is assumed to affect the latent variable interpreted as the propensity to participate in the labor market, but labor market participation is assumed not to affect the propensity to have a mortgage. Since the error terms are uncorrelated, probit estimation of the first equation alone provides consistent and efficient estimates of $\eta_{1}$ and $\beta_{1}$ under the model assumptions.

Model 2: $\quad \eta_{1}=\eta_{2}=0$

$$
\begin{aligned}
& y_{1 i}^{*}=x_{1 i} \beta_{1}+\delta_{1} y_{2 i}^{*}+\varepsilon_{1 i} \\
& y_{2 i}^{*}=x_{2 i} \beta_{2}+\delta_{2} y_{1 i}^{*}+\varepsilon_{2 i}
\end{aligned} .
$$

This corresponds to the classic linear simultaneous equation model, except that the dependent variables in the system are all latent. Identification conditions are identical to those 
in the model for which the dependent variables are observable. In the absence of restrictions on the covariance matrix, exclusion restrictions are required. Many more restrictions are imposed in the estimated specifications than are required for identification. In addition, the "coherency" condition $\left(1-\delta_{1} \delta_{2}>0\right)$ must be satisfied for the model to be a well-defined probabilistic structure. This condition is not imposed in the estimation of the model, but is checked at the model estimates. The ln likelihood function for this model is reported in Appendix 2.

\section{Empirical Estimation}

In our empirical work, we consider the following sets of variables as candidates for exogenous determinants of the wife's probability of working and of mortgage use:

\section{Personal characteristics}

In this set we include wife's age and schooling, husband's schooling, number of children between zero and six years of age, household's income (residual income after wife's earnings, expressed in 1993 million liras) and region of residence (a dummy variable equal to 1 if they live in the North and Center of Italy).

\section{Family economic contributions}

As mentioned before, the extended family has a role in trying to compensate for the limited borrowing opportunities in the Italian mortgage market. Many homeowners received their house as a gift or bequest. Debts to relatives are also important in describing the family's contribution. We account for both types of family contributions in the empirical work.

\section{Other debts}


The survey provides information on other household debt (debts on cars, installment payments on household appliances, etc.). We include those debts in our empirical work. They allow us to examine whether the effect of the mortgage is different from that of other types of debt. Additionally, they also serve as indicators of attitudes towards debt.

\section{The credit system}

The survey reports data on the respondent's relationship with banks and on other variables that measure access to credit markets. For example, households are asked whether they have a checking account, how many banks they use, and how many credit cards they hold. The use of these variables is appropriate for the Italian case, where a relevant fraction of households do not have a checking account (but have, for example, a post office saving account), and a very small fraction of households have credit cards. These variables can be useful for identifying different types of borrowers and also for picking up different degrees of asymmetric information that could affect bank lending.

Indicators of the financial market changes occurring between 1989 and 1993 are particularly important for our paper. We used a variable indicating whether the house was purchased after 1992 to capture the effects of the financial liberalization. This variable allows us to assess the effect of changes in the credit market and has the advange of being strictly exogenous. The effect of this variable should be positive and significant, expecially for younger households who are more likely to apply for a mortgage. After 1992, a greater access to the mortgage market was available to Italian families, in particular those living in the Northern-Central regions where changes in the credit market happened relatively more rapidly. 


\subsection{Empirical Results}

In Tables 4 and 5, we report Model 1, i.e., probit estimates for the 1989 and 1993 samples of homeowners, excluding those who received their house as a gift or bequest. We also compute similar probits for full samples. We use two different indicators for mortgage debt. The first is a dummy variable indicating whether the household has a mortgage debt (I Specification), and the second indicates the mortgage amount still owed (II Specification).

As expected, younger women are more likely to work, while the presence of young children decreases the probability of working. The schooling of the wife is always positive and very significant, while the household income (residual income after wives' earnings) is always negative and significant. Living in the Northern-Central regions significantly increases the probability of working.

Both the dummy indicating that the household has a mortgage debt and the variable indicating the residual mortgage debt are positive and significant. Thus, even after controlling for many variables that affect participation, we still find that having a mortgage has an effect on the wife's labor market participation. When considering the entire homeowner sample, we find that having received a house as a gift or bequest (thus having never faced a financing decision) has a negative effect on female participation. ${ }^{\square}$ We also included a variable indicating whether the household has other debt in two variants: as a dummy and as the remaining amount owed. We find that the estimates for other types of debt are not statistically significant.

We also introduced two different indicators for family debt (including mortgage debt) into the equation: a dummy indicating whether the family has a debt with relatives and the amount owed. The most interesting finding is that the effect of family debt is substantially 
different between 1989 and 1993. While in 1989 the coefficient is greater in magnitude and statistically significant, in 1993 it is not statistically different from zero. This is consistent with the fact that households tend to rely much more on financial markets after 1992. The importance and characteristics of family loans among Italian households is well documented in Cigno et al. (1998). The authors show that family transfers are often re-paid with time transfers (in terms of services and help with housework).

The results of a probit on the pooled sample (1989 and 1993, with a year dummy for 1993) are presented in Table 6. The year dummy captures the effect of macroeconomic conditions, such as changes in interest rates and the slow-down of the economy. All estimates of the variables related to personal characteristics are similar to those of the 1989 and 1993 samples. The estimates related to the financial position of the household seem to be a little more significant in a temporal context, while the dummy for the year is positive but not significantly different from zero. The coefficient of the mortgage is positive and statistically different from zero, while the coefficients related to other debts are not significant.

Tables 7 reports Model 2 estimates (the latent variable model) in 1989 and 1993. This specification shows evidence of simultaneity: the correlation between the structural disturbances is estimated to be approximately -0.772 (with a standard error of .145) in 1989 and -.835 . (with a standard error of .095) in 1993. We note that, while there is some evidence for simultaneity, there is no strong evidence of non-recursiveness. The propensity of the wife to work has a positive direct effect on the mortgage propensity, but the estimated coefficient is only marginally significantly different from zero. The coefficients are .262 with a .124 standard error in 1989 and .217 with a standard error of .125 in 1993 . Conversely, the effect of the mortgage propensity on the wife's participation is positive and statistically significant

\footnotetext{
${ }^{8}$ For brevity, estimates are not reported but are available from the authors upon request.
} 
in both years (.804 with a standard error of .118 in 1989 , and .783 with a standard error of .087 in 1993). As for family debt, the coefficient is not significant in both years.

All variables related to credit access (such as having a checking account, various bank accounts, or credit cards) have a positive effect on the probability of having a mortgage. A comparison between the coefficients of these variables in the two years shows that their effect is larger overall in 1993 and is also more significant.

Table 8 reports the empirical results for the pooled sample. The coefficients of age, age squared, education and the number of children 0-6 have the expected sign. Living in the North-Center increases the probability of working, while the variables related to income and family debts are not significant. The variable related to other debt is positive and marginally significant. The pooled sample specification also contains the variable indicating whether the family bought the house after 1992. Its coefficient is positive and significantly different from zero. This suggests that purchasing a house after 1992 increases the probability of using mortgages (the estimate is very significant, the coefficient is four times the standard error).

Consistent with the aggregate evidence reflecting institutional changes, homeowners were much more likely to have a mortgage in 1993 than in 1989 . The year dummy is in fact very significant in the mortgage equation. However, it is actually negative in the wife's labor market participation equation. This result is important, especially when compared with the positive effect of the mortgage propensity that seems to offset the negative time effect on women' labor market participation.

In Table 9, we report likelihood ratio statistics used to test the time-invariance of the relationships specified in the model. In the first test, the null hypothesis of no change is tested against the alternative that all parameters changed between 1989 and 1993. In the second test, 
the null hypothesis is that only the constant terms changed across the two periods. The results show that we can reject the hypothesis that nothing changed between the two years. The second test indicates that the change cannot be solely accounted for by shifts in intercepts, although these are important components of the temporal variability in the model. It is evident from comparison of the coefficients of the 1989 and 1993 equation that the relationships associated with the credit market variables changed more markedly.

We use the coefficients of the simultaneous equation model to compute the elasticities of labor market participation of wives and mortgage rates among homeowners with respect to changes in institutional settings in which agents operate (as measured by changes in constant terms of the two equations). The cross-elasticity of labor market participation is defined as the percentage change in the probability of labor market participation induced by a shift in the constant term of the mortgage equation, divided by the percentage change in the constant term

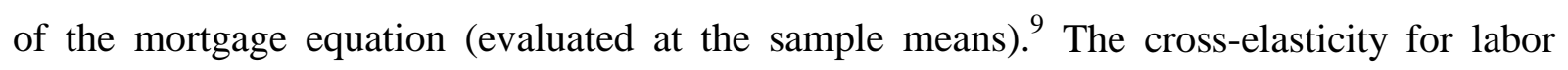
market participation is .599 . This indicates that there is some responsiveness in labor market participation to changes in the structure of the mortgage market, even though it is not quantitatively large. However, it does give predictions consistent with the empirical evidence over the sample period. Over this period, mortgage usage among homeowners increased from 13 to 28 percent, while participation of wives in the homebuyers (as opposed to homeowners) sample increased from 45.4 to 50.4 percent. Using the elasticities mentioned above, for this rate of growth in mortgage usage, we predict an increase in participation from 45.4 to 52.2 percent, which is close to the observed growth rate over the period 1989-1993. This seems to lend credibility to our model estimates and our conceptualization of the policy experiment. 


\subsection{Young Households and Households Living in the Northern-Central Regions.}

As we discussed earlier, given the pattern of homeownership across age groups, it is the younger households that benefit the most from the changes in the mortgage market. We estimate the simultaneous equation model for the sample of young families (wives younger than 38) for the pooled sample 1989-1993. The coefficients are coeherent with the results presented for the whole sample (Table 10, second and third columns). The variable indicating whether the household bought the house after 1992 is positive and significant. This suggests that, for younger households, purchasing a house after 1992 increases the probability of using a mortgage. However, an important difference seems to emerge from the comparison of the effects of the latent variables. While the effect of the mortgage propensity on the wife's participation decision remains large and statistically significant (.716 with a standard error of .111), the effect of the wife's participation propensity on the mortgage decision is not significantly different from zero (the estimate is .204 with a .130 standard error). While there is still evidence of simultaneity, there is no evidence of non-recursiveness for this sample. Only the mortgage propensity is significant in the probability of women working, but not the other way around. This result is coherent with our hypothesis that it is the changes in the mortgage market affect the participation in the labor market.

We also re-estimate the model on the sample of households that live in the NorthCenter of Italy, where a greater number of foreign banks entered during the period of observation and a larger number of morgages were given. The estimates are presented in Table 10 (fourth and fifth columns). In the participation equation, the variables related to age, number of children, and schooling maintain the same sign. The dummy for the year 1993 is still negative and significant in the participation equation. In the mortgage equation, the

\footnotetext{
${ }^{9}$ See also Appendix 3.
} 
variables age, age squared and income maintain the same sign. The variables related to the banking system remain positive. Only the variable indicating whether the household has a checking account is not significant, which is perhaps explained by the widespread use of banks in these regions. Buying a house after 1992 is significant but less than in the previous results for the whole sample. There is still evidence of simultaneity but less of nonrecursiveness.

To summarize, the simultaneous equation model estimates in all specifications provide evidence that indicates that the growth in female labor participation (which displays a long-term trend in Italy, as in most advanced countries) has been affected by changes in the credit market. Credit markets have allowed a wider access to mortgages, but maintained high costs of re-payment. For younger households, there is strong evidence that the model is recursive. There are reasons to expect that selection (in terms of the wife being a steady labor market participant for the household to qualify for a mortgage) may be more important among younger households who are likely to have lower levels of assets in general. Thus, we believe

that this adds evidence of the direct impact of having a mortgage on the likelihood of participation in the labor market.

\section{Conclusions}

As a result of increased competition and changes in banking regulations in Italy from 1989-1993, the number of mortgages as well as their average amount markedly increased. However, duration of mortgages did not substantially change. The burden of the housing debt was not reduced, but rather shifted from the accumulation of the down-payment to the repayment of the mortgage debt. 
Using a simultaneous equation framework, we analyzed the effect of changes in mortgage usage on the labor market decisions of Italian households. The estimates indicate that mortgage use does have a significant impact on the labor market participation of wives over the 1989-93 period. Our empirical analysis shows that there are important spillover effects from financial markets to the labor market and that the financial liberalization currently in progress can be expected to influence female labor market participation in Italy. 


\section{TABLE 3a}

\section{Participation Rates of Husbands and Wives across Financing Modes 1989}

$\begin{array}{lrrrrrr} & \text { All } & \begin{array}{c}\text { Home- } \\ \text { owners }\end{array} & \text { Buyers } & \begin{array}{c}\text { Buyers } \\ \text { with } \\ \text { Mortgage }\end{array} & \begin{array}{r}\text { Gift and } \\ \text { Bequest }\end{array} & \text { Renters } \\ \text { Husband's Age } & 42.5 & 44.0 & 44.6 & 41.5 & 41.7 & 40.1 \\ \text { Wife's Age } & 39.0 & 40.3 & 40.9 & 38.3 & 38.1 & 36.8 \\ \text { Husband's Participation } & 98.3 & 98.7 & 99.0 & 99.6 & 97.9 & 97.5 \\ \text { Wife's Participation } & 41.5 & 43.7 & 45.4 & 57.0 & 41.1 & 37.0 \\ \text { Husband's Hours of Work } & 41.4 & 41.6 & 41.7 & 41.4 & 41.0 & 41.2 \\ \text { Wife's Hours of Work } & 15.5 & 16.5 & 17.0 & 20.8 & 15.3 & 13.7 \\ \text { North } & 38.6 & 37.2 & 38.6 & 40.9 & 32.1 & 41.0 \\ \text { Husband's Schooling } & 9.5 & 9.6 & 9.5 & 10.6 & 9.7 & 9.3 \\ \text { Wife's Schooling } & 9.0 & 9.1 & 9.1 & 10.3 & 9.2 & 8.9 \\ \text { Number of Children } & 1.7 & 1.7 & 1.7 & 1.7 & 1.7 & 1.6 \\ \text { Number of Children 0-6 } & 0.36 & 0.32 & 0.29 & 0.39 & 0.43 & 0.43 \\ \text { Husband's Income } & 22.5 & 23.3 & 23.8 & 25.4 & 21.1 & 21.2 \\ \text { Wife's Income } & 7.0 & 7.5 & 7.8 & 10.1 & 6.8 & 6.0 \\ \text { \% Family Debts } & 3.8 & 3.1 & 3.3 & 7.5 & 2.5 & 4.9 \\ \text { \% Other Debts } & 9.9 & 7.9 & 8.0 & 11.6 & 7.6 & 13.1 \\ & & & & & & \\ \text { Sample Size } & (3,562) & (2,219) & (1,750) & (293) & (469) & (1,343)\end{array}$




\section{TABLE 3b}

\section{Participation Rates of Husbands and Wives across Financing Modes}

1993

$\begin{array}{lrrrrrr} & \text { All } & \begin{array}{c}\text { Home- } \\ \text { owners }\end{array} & \text { Buyers } & \begin{array}{c}\text { Buyers } \\ \text { with } \\ \text { Mortgage }\end{array} & \begin{array}{r}\text { Gift and } \\ \text { Bequest }\end{array} & \text { Renters } \\ \text { Husband's Age } & 42.9 & 43.7 & 44.0 & 42.2 & 42.6 & 41.2 \\ \text { Wife's Age } & 39.4 & 40.1 & 40.3 & 39.0 & 39.1 & 38.0 \\ \text { Husband's Participation } & 96.6 & 97.6 & 98.2 & 99.0 & 95.1 & 94.3 \\ \text { Wife's Participation } & 43.8 & 48.9 & 50.4 & 58.9 & 42.7 & 33.4 \\ \text { Husband's Hours of Work } & 40.1 & 40.6 & 40.8 & 41.6 & 39.5 & 39.2 \\ \text { Wife's Hours of Work } & 14.7 & 16.2 & 16.8 & 19.8 & 13.5 & 11.6 \\ \text { North } & 39.6 & 38.4 & 39.9 & 39.9 & 31.9 & 42.2 \\ \text { Husband's Schooling } & 9.6 & 9.9 & 9.8 & 10.6 & 10.0 & 9.0 \\ \text { Wife's Schooling } & 9.3 & 9.5 & 9.5 & 10.3 & 9.5 & 8.7 \\ \text { Number of Children } & 1.7 & 1.7 & 1.6 & 1.6 & 1.7 & 1.7 \\ \text { Number of Children 0-6 } & 0.37 & 0.34 & 0.31 & 0.35 & 0.46 & 0.44 \\ \text { Husband's Income } & 25.6 & 27.0 & 27.8 & 30.0 & 23.9 & 22.7 \\ \text { Wife's Income } & 8.4 & 9.6 & 10.0 & 12.0 & 7.8 & 5.8 \\ \text { \% Family Debts } & 5.2 & 4.9 & 5.7 & 6.6 & 3.4 & 5.6 \\ \text { \% Other Debts } & 16.7 & 12.7 & 13.3 & 17.5 & 10.2 & 25.0 \\ & & & & & & \\ \text { Sample Size } & (2,712) & (1,828) & (1,477) & (513) & (351) & (884)\end{array}$




\section{TABLE 4 \\ Probability of Wife Working \\ (Model 1) \\ 1989}

$\begin{array}{lrrrr}\text { Variable } & \text { Estimates } & \text { s.e. } & \text { Estimates } & \text { s.e. } \\ \text { Constant } & -2.494 & 0.816 & -2.552 & 0.817 \\ \text { Wife's Age/10 } & 0.442 & 0.407 & 0.493 & 0.407 \\ \text { Wife's Age Squared } & -0.053 & 0.050 & -0.059 & 0.050 \\ \text { Number of Children 0-6 } & -0.070 & 0.069 & -0.069 & 0.069 \\ \text { North-Center } & 0.619 & 0.069 & 0.609 & 0.069 \\ \text { Wife's Schooling } & 0.140 & 0.012 & 0.141 & 0.012 \\ \text { Husband's Schooling } & -0.007 & 0.011 & -0.007 & 0.011 \\ \text { Income/100 } & -0.307 & 0.097 & -0.321 & 0.097 \\ \text { Mortgage (Dummy) } & 0.250 & 0.089 & & \\ \text { Mortgage (Amount) } & & & 0.005 & 0.002 \\ \text { Family Debts } & -0.380 & 0.193 & -0.027 & 0.013 \\ \text { Other Debts } & 0.202 & 0.113 & 0.004 & 0.007 \\ & & & & \\ \text { Sample Size } & 1,750 & & & \end{array}$

I Specification II Specification 
TABLE 5

\section{Probability of Wife Working (Model 1) \\ 1993}

$\begin{array}{lrrrr}\text { Variable } & \text { Estimates } & \text { s.e. } & \text { Estimates } & \text { s.e. } \\ \text { Constant } & -4.405 & 0.919 & -4.453 & 0.924 \\ \text { Wife's Age/10 } & 1.348 & 0.463 & 1.381 & 0.465 \\ \text { Wife's Age Squared } & -0.167 & 0.058 & -0.172 & 0.058 \\ \text { Number of Children 0-6 } & -0.263 & 0.075 & -0.278 & 0.076 \\ \text { North-Center } & 0.615 & 0.079 & 0.618 & 0.079 \\ \text { Wife's Schooling } & 0.158 & 0.013 & 0.157 & 0.013 \\ \text { Husband's Schooling } & 0.027 & 0.013 & 0.027 & 0.013 \\ \text { Income/100 } & -0.792 & 0.176 & -0.765 & 0.179 \\ \text { Mortgage (Dummy) } & 0.129 & 0.077 & & \\ \text { Mortgage (Amount) } & & & 0.003 & 0.001 \\ \text { Family Debts } & 0.061 & 0.161 & 0.011 & 0.008 \\ \text { Other Debts } & 0.057 & 0.105 & 0.015 & 0.011 \\ & & & & \\ \text { Sample Size } & 1,477 & & 1,477 & \\ \text { Log Likelihood } & & & & \end{array}$


TABLE 6

\section{Probability of Wife Working (Model 1) Pooled sample 1989-1993}

Variable

Constant

Wife's Age/10

Wife's Age Squared

Number of Children 0-6

North-Center

Wife's Schooling

Husband's Schooling

Income/100

Mortgage (Dummy)

Mortgage (Amount)

Family Debts

Other Debts

Year 1993

Sample Size

Log Likelihood
I Specification

Estimates

$-3.326$

0.847

$-0.105$

$-0.149$

0.594

0.148

0.003

$-0.413$

0.178

$-0.125$

0.124

0.012

3,227

$-1,838.77$
II Specification

s.e. Estimates s.e.

$\begin{array}{lll}0.606 & -3.365 & 0.608\end{array}$

0.304

0.038

0.050

0.051

0.008

0.008

0.084

0.058

0.877

0.304

$-0.109$

0.038

$-0.154$

0.051

0.594

0.051

0.148

0.008

0.002

0.008

$-0.408$

0.085

$0.004 \quad 0.001$

0.121

0.078

0.049

$-0.0007$

0.005

0.007

0.006

0.027

0.049

3,227

$-1,833.79$ 


\section{TABLE 7}

\section{Simultaneous Equation Model with Latent Variables}

(Model 2)

1989

1993

Estimates s.e. Estimates s.e.

\section{Wife's Participation Equation}

Constant

Wife's Age/10

Wife's Age Squared

Number of Children 0-6

North-Center

Wife's Schooling

Income $/ 100$

Family Debts

Other Debts

Mortgage Propensity
$-0.574$

$-0.748$

0.117

$-0.048$

0.538

0.807

0.041

$-0.135$

0.140

0.804

\section{Mortgage Equation}

Constant

Wife's Age/10

Wife's Age Squared

North-Center

Income/100

Husband's Schooling

Bank

More Banks

Credit Card

Work Propensity

$\rho$

Sample Size

Log Likelihood
1,750

$-3.187$

1.484

$-0.021$

$-0.248$

$-0.434$

$-0.020$

0.168

0.233

0.083

0.262

$-0.772$

1,750

$-1,748.73$
1.051

0.494

0.062

0.055

0.102

0.233

0.192

0.089

0.057

0.087
0.939

0.462

0.058

0.085

0.193

0.094

0.111

0.071

0.077

0.125

0.095 
TABLE 8

Simultaneous Equation Model with Latent Variables (Model 2)

Pooled sample 1989-1993

\section{Wife's Participation Equation}

Estimates s.e.

Constant

$-0.994$

0.228

Wife's Age

$0.112 \quad 0.040$

Wife's Age Squared

$-0.114$

0.038

Number of Children 0-6

$-0.178$

0.065

North-Center

0.307

0.077

Wife's Schooling

0.954

0.147

Income/100

$-0.024$

0.087

$-0.057$

0.083

Other Debts

0.107

0.055

Year 1993

$-0.313$

0.068

Mortgage Propensity

0.645

0.081

Mortgage Equation

Constant

$-0.488$

0.186

Wife's Age/10

$-0.157$

0.031

Wife's Age Squared

$-0.087$

0.062

North-Center

$-0.001$

0.073

Income/100

$-0.529$

0.113

Husband's Schooling

0.116

0.066

0.241

0.084

More Banks

0.236

0.053

0.140

0.048

Credit Cards

0.508

0.052

Bought House After 1992

0.431

0.108

Work Propensity

0.215

0.075

$-0.718$

0.092

Sample Size

Log Likeliood

$-3,470.51$ 


\section{TABLE 9}

\section{TEST STATISTICS}

1. $\mathrm{L}_{1}=-1,748.726-1,707.367=-3,456.093$ (21 restrictions) all parameters changed 2. $\mathrm{L}_{2}=-3,482.901$ (19 restrictions) only constants changed

3. $\mathrm{L}_{3}=-3,543.504$ (21 restrictions) nothing changed

TEST 1 all parameters changed between 1989 and 1993 (vs. nothing changed)

$\mathrm{H}_{\mathrm{O}}:(3)$

$\mathrm{H}_{\mathrm{A}}:(1)$

$2\left[\mathrm{~L}_{1}-\mathrm{L}_{3}\right]=174.822$, prob. under the null $<.0001$

TEST 2 the constant terms changed (vs. everything changed)

$\mathrm{H}_{\mathrm{O}}:(2)$

$\mathrm{H}_{\mathrm{A}}:(1)$

$2\left[\mathrm{~L}_{1}-\mathrm{L}_{2}\right]=53.62$, prob. under the null $<.0001$ 
Wife's Participation Equation

Constant

Wife's age/10

Wife's Age Squared

Number of Children 0-6

North-Center

Wife's Schooling

Income/100

Family Debts

Other Debts

Year 1993

Mortgage Propensity

\section{Mortgage Equation}

Constant

Wife's Age/10

Wife's Age Squared

North-Center

Income/100

Husband's Schooling

Bank

More Banks

Credit Cards

Year 1993

Bought House after 1992

Work Propensity

$\rho$

Sample size

Log Likelihood

TABLE 10

Simultaneous Equation Model with Latent Variables

(Model 2)

Pooled sample 1989-1993

Young Households

(wife younger than 38)
Households Living in Northern-Central Regions

$\begin{array}{rrrr}\text { Estimates } & \text { s.e. } & \text { Estimates } & \text { s.e. } \\ & & & \\ -0.587 & 0.315 & -0.254 & 0.881 \\ & & 0.113 & 0.429 \\ & & -0.002 & 0.054 \\ -0.144 & 0.053 & -0.146 & 0.052 \\ 0.346 & 0.126 & & \\ 0.869 & 0.232 & 0.756 & 0.176 \\ 0.370 & 0.177 & 0.032 & 0.177 \\ -0.050 & 0.110 & -0.072 & 0.110 \\ 0.163 & 0.090 & 0.088 & 0.064 \\ -0.357 & 0.098 & -0.473 & 0.089 \\ 0.716 & 0.111 & 0.722 & 0.093\end{array}$

$\begin{array}{rcrr}-0.787 & 0.193 & -1.806 & 0.862 \\ & & 0.585 & 0.435 \\ 0.074 & 0.104 & -0.093 & 0.055 \\ -0.784 & 0.187 & -0.693 & 0.163 \\ 0.126 & 0.108 & 0.008 & 0.063 \\ 0.028 & 0.120 & 0.173 & 0.139 \\ 0.297 & 0.094 & 0.202 & 0.063 \\ 0.154 & 0.081 & 0.168 & 0.058 \\ 0.468 & 0.084 & 0.659 & 0.066 \\ 0.286 & 0.139 & 0.398 & 0.136 \\ 0.204 & 0.130 & 0.305 & 0.103 \\ -0.722 & 0.150 & -0.813 & 0.092\end{array}$

1,113

2,023

$-1,273.93$ 


\begin{abstract}
APPENDIX 1
Sample Selection criteria

In this Appendix we report a list of the selection rules in our sample

TABLE A.1

SAMPLE SELECTION

\section{Selection criteria}

1. Only married couples.

2. Only families in which neither the wife nor the husband own a business.

3. Only families with wives in the age bracket 20-55 and husbands 20-59.

4. Only families in which neither the husbands or wives have zero incomes or are retired and report non-zero income if they work.

5. Only families which either rent or own.

6. Only families with no missing values in mortgages, year of house purchasing.

7. Only families whose residual income (total - wife's labor earnings) is non-negative or zero.

8. Only homeowners.
\end{abstract}




\section{APPENDIX 2}

The log-likelihood function for Model 2 is:

$$
\begin{aligned}
L\left(\vartheta_{2}\right) & =\sum_{i \in S_{00}} \ln \int^{-\tilde{m}_{1 i}} \int^{-\tilde{m}_{2 i}} f(u, v ; \tilde{\rho}) \partial u \cdot \partial v \\
& +\sum_{i \in S_{01}} \ln \int^{-\tilde{m}_{1 i}} \int_{-\tilde{m}_{2 i}} f(u, v ; \tilde{\rho}) \partial u \cdot \partial v \\
& +\sum_{i \in S_{10}} \ln \int_{-\tilde{m}_{1 i}} \int^{-\tilde{m}_{2 i}} f(u, v ; \tilde{\rho}) \partial u \cdot \partial v \\
& +\sum_{i \in S_{11}} \ln \int_{-\tilde{m}_{1 i}} \int_{-\tilde{m}_{2 i}} f(u, v ; \tilde{\rho}) \partial u \cdot \partial v
\end{aligned}
$$

where:

$$
\begin{aligned}
& \tilde{m}_{1 i}=\frac{X_{1 i} \beta_{1}+\delta_{1} X_{2 i} \beta_{2}}{\tau_{1}} \\
& \tilde{m}_{2 i}=\frac{\delta_{2} X_{1 i} \beta_{1}+X_{2 i} \beta_{2}}{\tau_{2}} \\
& \tau_{1}=\left(1+\delta_{1}^{2}+2 \delta_{1} \rho\right)^{\frac{1}{2}} \\
& \tau_{2}=\left(1+\delta_{2}^{2}+2 \delta_{2} \rho\right)^{\frac{1}{2}} \\
& \tilde{\rho}=\frac{\delta_{1}+\delta_{2}+\rho\left(1+\delta_{1} \delta_{2}\right)}{\tau_{1} \tau_{2}} \\
& \vartheta_{2}=\left(\beta_{1}^{\prime} \beta_{2}^{\prime} \delta_{1} \delta_{2} \rho\right)^{\prime}
\end{aligned}
$$

All $\ln$ likelihoods were maximized using the MAXLIK procedure in GAUSS; numerical procedures were used to compute the gradient vector and the Hessian. No unusual problems were encountered in the process of estimating these functions, in part probably due to the relatively large sample size. In addition, to avoid possible problems we parameterized the correlation coefficient as $\rho=\tanh (\alpha)$, where $\alpha \in R$ and tanh denotes the hyperbolic tangent function. We then estimated $\alpha$ directly instead of $\rho$. The maximum likelihood estimate of $\rho$ is then $\tanh (\hat{\alpha})$, where $\hat{\alpha}$ denotes the m.l.e. of $\alpha$. The standard error of $\hat{\rho}$ was obtained using the delta method. 


\section{APPENDIX 3}

This appendix contains a description of the method used to compute the elasticities reported in Section 6 from the structural latent variable model of mortgages and participation. We consider the effect on behavior of shifts in the constant terms in the two equations, $\beta_{1}^{1}$ [in the participation equation] and $\beta_{2}^{1}$ [in the mortgage equation]. As discussed in the text, we interpret these shifts as resulting from changes in the institutional setting in which agents operate. The elasticities were computed for the non-recursive latent variable model without "structural shift," or Model 2. The reduced form of this model is:

$$
\begin{aligned}
& y_{1 i}^{*}=\left(1-\delta_{1} \delta_{2}\right)^{-1}\left(X_{1 i} \beta_{1}+\delta_{1} X_{2 i} \beta_{2}\right)+v_{1 i} \\
& y_{2 i}^{*}=\left(1-\delta_{1} \delta_{2}\right)^{-1}\left(X_{2 i} \beta_{2}+\delta_{2} X_{1 i} \beta_{1}\right)+v_{2 i}
\end{aligned},
$$

where:

$$
\begin{aligned}
& v_{1 i} \equiv\left(1-\delta_{1} \delta_{2}\right)^{-1}\left(\varepsilon_{1 i}+\delta_{1} \varepsilon_{2 i}\right) \\
& v_{2 i} \equiv\left(1-\delta_{1} \delta_{2}\right)^{-1}\left(\delta_{2} \varepsilon_{1 i}+\varepsilon_{2 i}\right) .
\end{aligned}
$$

Define:

$$
\begin{aligned}
& a_{1 i} \equiv\left(1-\delta_{1} \delta_{2}\right)^{-1}\left(X_{1 i} \beta_{1}+\delta_{1} X_{2 i} \beta_{2}\right) \\
& a_{2 i} \equiv\left(1-\delta_{1} \delta_{2}\right)^{-1}\left(X_{2 i} \beta_{2}+\delta_{2} X_{1 i} \beta_{1}\right) .
\end{aligned}
$$

Then the probability of agent $i$ participating in the labor market is:

$$
P\left(d_{1 i}=1 \mid X_{1 i}, X_{2 i}\right)=\Phi\left(a_{1 i} / \sigma_{v_{1}}\right),
$$

and the probability of agent $i$ having a mortgage is:

$$
P\left(d_{2 i}=1 \mid X_{1 i}, X_{2 i}\right)=\Phi\left(a_{2 i} / \sigma_{v_{2}}\right),
$$

where $\sigma_{v_{j}}$ is the standard deviation of the reduced-form disturbance in equation $j$.

Say that an institutional change lowered the barrier to having a mortgage - we model such an event as decreasing the constant term in the second structural latent variable equation. If $\beta_{2}^{1}$ is perturbed by some amount $\lambda$, then we can define the two elasticities:

$$
\begin{aligned}
& \zeta_{2,2}(\lambda)=\left[\Phi\left(\left\{a_{2 i}+\left(1-\delta_{1} \delta_{2}\right)^{-1} \lambda\right\} / \sigma_{v_{2}}\right) / \Phi\left(a_{2 i} / \sigma_{v_{2}}\right)-1\right] /\left[\lambda / \beta_{2}^{1}\right] \\
& \zeta_{1,2}(\lambda)=\left[\Phi\left(\left\{a_{1 i}+\left(1-\delta_{1} \delta_{2}\right)^{-1} \delta_{1} \lambda\right\} / \sigma_{v_{1}}\right) / \Phi\left(a_{1 i} / \sigma_{v_{1}}\right)-1\right] /\left[\lambda / \beta_{2}^{1}\right]
\end{aligned}
$$

The first elasticity in (A.2) is defined as the percentage change in the probability of agent $i$ having a mortgage associated with a perturbation of the constant term to $\beta_{2}^{1}+\lambda$ divided by the percentage change in the constant term. The "cross-elasticity" $\zeta_{1,2}(\lambda)$ is defined as the ratio of the percentage change in the probability of labor market participation induced by the shift in $\beta_{2}^{1}$ divided by the percentage change in $\beta_{2}^{1}$. 
Analogous elasticities are defined when the constant term in first structural equation is perturbed by some amount $\lambda$. These are given by:

$$
\begin{aligned}
& \zeta_{1,1}(\lambda)=\left\lfloor\Phi\left(\left\{a_{1 i}+\left(1-\delta_{1} \delta_{2}\right)^{-1} \lambda\right\} / \sigma_{v_{1}}\right) / \Phi\left(a_{1 i} / \sigma_{v_{1}}\right)-1\right] /\left[\lambda / \beta_{1}^{1}\right] \\
& \zeta_{2,1}(\lambda)=\left[\Phi\left(\left\{a_{2 i}+\left(1-\delta_{1} \delta_{2}\right)^{-1} \delta_{2} \lambda\right\} / \sigma_{v_{2}}\right) / \Phi\left(a_{2 i} / \sigma_{v_{2}}\right)-1\right] /\left[\lambda / \beta_{1}^{1}\right]
\end{aligned}
$$

where $\zeta_{1,1}(\lambda)$ is the percentage change of the participation probability induced by a perturbation of $\lambda$ in the coefficient $\beta_{1}^{1}$ in the structural participation equation. $\zeta_{2,1}(\lambda)$ is the elasticity of the mortgage rate defined with respect to the same perturbation. 


\section{Bibliography}

Aaberge R., U. Colombino, and S. Strom (1999), "Labour Supply in Italy: An Empirical Analysis of Joint Household Decisions, with Taxes and Quantity Constraints." Journal of Applied Econometrics 14: 403-22.

Aldershof T., R. Alessie, and A. Kapteyn (1996), "Female Labor Supply and the Demand for Housing." Working Paper, CentER, Tilburg University.

Alessie R., B. Melenberg, and G. Weber (1988), "Consumption, Leisure, and EarningsRelated Liquidity Constraints: A Note." Economic Letters 27: 101-104.

Bernhardt, D. and D. Backus (1990), "Borrowing Constraints, Occupational Choice, and Labor Supply,” Journal of Labor Economics 8: 145-173.

Blanchflower, D. and A. Oswald (1998), "What Makes an Entrepreneur?" Journal of Labor Economics 16: 26-60.

Browning M., and A. Lusardi (1996), "Household Saving: Micro Theories and Micro Facts." Journal of Economic Literature 34: 1797-1855.

Caplin A., S. Chan, C. Freeman, and J. Tracy (1997), Housing Partnership: A New Approach to a Market at a Cross-Roads. MIT Press.

Casini M. (1995) "Il Credito Immobiliare." Bank of Italy, Milan.

Chiuri M.C. and T. Jappelli (2002), "Financial Market Imperfections and Home Ownership:A Comparative Study." CSEF, University of Salerno.

Cigno A., G. Giannelli, and F. Rosati (1998), "Voluntary Transfers among Italian Households; Altruistic and Non-Altruistic Explanations." Structural Change and Economic Dynamics 9: 435-451.

Dau-Schmidt K. (1997), "An Empirical Study of the Effect of Liquidity and Consumption Commitment Constraints on Intertemporal Labor Supply." Journal of Economics 23: 89-105.

Del Boca D., and C. Flinn (1985), "Self-Reported Reservation Wages and Labor Market Decisions." Ricerche Economiche 3: 363-383.

Del Boca D., and A. Lusardi (1999), "Finanziamento dell'Abitazione e Offerta di Lavoro." Studi e Modelli per la Politica Economica, SADIBA-Banca d'Italia, Rome.

Eberly, J. (1994), "Adjustments of Consumers' Durable Stocks: Evidence from Automobile Purchases." Journal of Political Economy 103: 403-436. 
Engelhardt G., and C. Meyer (1994), "Gifts, Down Payments, and Housing Affordability." Working Paper No. 94-5, Federal Reserve Bank of Boston.

Engelhardt G. (1996,) "Consumption, Down-Payments and Liquidity Constraints." Journal of Money, Credit and Banking 28: 255-271.

Ermisch J., and B. Halpin (2000,) "Becoming a Homeowner in Britain in the 1990s." ISER Working Paper, University of Essex.

Evans D. and Jovanovic B.(1989), “An Estimated Model of Entrepreneurial Choice under Liquidity Constraints," Journal of Political Economy 97, 808-827.

European Mortgage Federation (1989), Hypostat 1989-1999. Brussels.

Evans D, and L. Leighton (1989), "Some Empirical Aspects of Entrepreneurship," American Economic Review 79: 519-535.

Fairlie, R (1999), "The Absence of African-American Owned Business: An Analysis of the Dynamics of Self-Employment," Journal of Labor Economics 17: 80-108.

Fortin N. (1995), "Allocation Inflexibilities, Female Labor Supply and Housing Assets Accumulation: Are Women Working to Pay the Mortgage?" Journal of Labor Economics 3: 524-557.

Garcia R., A. Lusardi, and S. Ng (1997), "Excess Sensitivities and Asymmetries in Consumption: An Empirical Investigation." Journal of Money, Credit and Banking 29: 154176.

Generale A, and G. Gobbi (1995),"Il Recupero dei Crediti: Prime Indicazioni su Costi, Tempi e Comportamenti delle Banche." Discussion Papers, Bank of Italy.

Guiso L., and T. Jappelli (1991), "Intergenerational Transfers and Capital Market Imperfections: Evidence from a Cross-Section of Italian Households." European Economic Review 31: 103-120.

Guiso L., and T. Jappelli (2002), "Private Transfers, Borrowing Constraints, and Timing of Homeownership." Journal of Money, Credit and Banking 34: 315-339.

Haurin D., S. Wachter, and P. Hendershott (1995), "Wealth Accumulation and Housing Choices of Young Households." NBER Working Paper 5070.

Heckman J. (1978), "Dummy Endogenous Variables in a Simultaneous Equation System." Econometrica 46: 931-959.

Holtz-Eakin, D., D. Joulfaian and H. Rosen (1994), "Sticking It Out: Entrepreneurial Survival and Liquidity Constraints," Journal of Political Economy 102, 53-75. 
Miles D. (1992), "The Financial Liberalization of the European Markets." European Economic Review 36: 1093-1136.

Phillips R., and J. Vanderhoff (1991), "Two-Earner Households and Housing Demand: The Effect of the Wife's Occupational Choice." Journal of Real Estate Finance and Economics 4: 83-91.

Villosio C. (1995), "Mercato del Credito, Proprieta' della Casa, Risparmio delle Famiglie." Fondazione Luigi Einaudi, Torino.

Yoshikawa H., and F. Ohtake (1989), "An Analysis of Female Labor Supply, Housing Demand and the Saving Rate in Japan." European Economic Review 2: 999-1023.

Zeldes S. (1989), "Consumption and Liquidity Constraints: An Empirical Investigation." Journal of Political Economy 97: 305-346. 


\section{IZA Discussion Papers}

\begin{tabular}{|c|c|c|c|c|}
\hline No. & Author(s) & Title & Area & Date \\
\hline 583 & $\begin{array}{l}\text { P. Cahuc } \\
\text { F. Fontaine }\end{array}$ & $\begin{array}{l}\text { On the Efficiency of Job Search with Social } \\
\text { Networks }\end{array}$ & 5 & 09/02 \\
\hline 584 & $\begin{array}{l}\text { C. J. Heinrich } \\
\text { P. R. Mueser } \\
\text { K. R. Troske }\end{array}$ & $\begin{array}{l}\text { Welfare to Temporary Work: Implications for } \\
\text { Labor Market Outcomes }\end{array}$ & 3 & $09 / 02$ \\
\hline 585 & $\begin{array}{l}\text { M. Cervellati } \\
\text { U. Sunde }\end{array}$ & $\begin{array}{l}\text { Human Capital Formation, Life Expectancy and } \\
\text { the Process of Economic Development }\end{array}$ & 3 & 09/02 \\
\hline 586 & $\begin{array}{l}\text { P. Díaz-Vázquez } \\
\text { D. Snower }\end{array}$ & $\begin{array}{l}\text { On-the Job Training and the Effects of Insider } \\
\text { Power }\end{array}$ & 3 & $09 / 02$ \\
\hline 587 & $\begin{array}{l}\text { H. Bonin } \\
\text { W. Kempe } \\
\text { H. Schneider }\end{array}$ & $\begin{array}{l}\text { Kombilohn oder Workfare? Zur Wirksamkeit } \\
\text { zweier arbeitsmarktpolitischer Strategien }\end{array}$ & 3 & $09 / 02$ \\
\hline 588 & M. Frölich & $\begin{array}{l}\text { Nonparametric IV Estimation of Local Average } \\
\text { Treatment Effects with Covariates }\end{array}$ & 6 & $09 / 02$ \\
\hline 589 & $\begin{array}{l}\text { S. Jurajda } \\
\text { K. Terrell }\end{array}$ & $\begin{array}{l}\text { Job Growth in Early Transition: Comparing Two } \\
\text { Paths }\end{array}$ & 4 & $09 / 02$ \\
\hline 590 & $\begin{array}{l}\text { H. Görg } \\
\text { E. Strobl } \\
\text { F. Walsh }\end{array}$ & $\begin{array}{l}\text { Why Do Foreign-Owned Firms Pay More? } \\
\text { The Role of On-the-Job Training }\end{array}$ & 2 & $10 / 02$ \\
\hline 591 & $\begin{array}{l}\text { H. Görg } \\
\text { E. Strobl }\end{array}$ & $\begin{array}{l}\text { Spillovers From Foreign Firms Through Worker } \\
\text { Mobility: An Empirical Investigation }\end{array}$ & 1 & $10 / 02$ \\
\hline 592 & J. Wagner & $\begin{array}{l}\text { Testing Lazear's Jack-of-All-Trades View of } \\
\text { Entrepreneurship with German Micro Data }\end{array}$ & 5 & $10 / 02$ \\
\hline 593 & $\begin{array}{l}\text { T. K. Bauer } \\
\text { P. J. Dross } \\
\text { J. P. Haisken-DeNew }\end{array}$ & Sheepskin Effects in Japan & 1 & $10 / 02$ \\
\hline 594 & $\begin{array}{l}\text { S. C. Wolter } \\
\text { M. Coradi Vellacott }\end{array}$ & $\begin{array}{l}\text { Sibling Rivalry: A Look at Switzerland with } \\
\text { PISA Data }\end{array}$ & 2 & $10 / 02$ \\
\hline 595 & $\begin{array}{l}\text { W. Arulampalam } \\
\text { A. L Booth } \\
\text { M. L. Bryan }\end{array}$ & $\begin{array}{l}\text { Work-Related Training and the New National } \\
\text { Minimum Wage in Britain }\end{array}$ & 3 & $10 / 02$ \\
\hline 596 & $\begin{array}{l}\text { H. Görg } \\
\text { E. Strobl }\end{array}$ & $\begin{array}{l}\text { Relative Wages, Openness and Skill-Biased } \\
\text { Technological Change }\end{array}$ & 2 & $10 / 02$ \\
\hline 597 & $\begin{array}{l}\text { S. M. Fuess, Jr. } \\
\text { M. Millea }\end{array}$ & $\begin{array}{l}\text { Disentangling Pay and Productivity in a } \\
\text { Corporatist Economy: The Case of Germany }\end{array}$ & 5 & $10 / 02$ \\
\hline 598 & $\begin{array}{l}\text { D. Del Boca } \\
\text { A. Lusardi }\end{array}$ & $\begin{array}{l}\text { Credit Market Constraints and Labor Market } \\
\text { Decisions }\end{array}$ & 2 & $10 / 02$ \\
\hline
\end{tabular}

